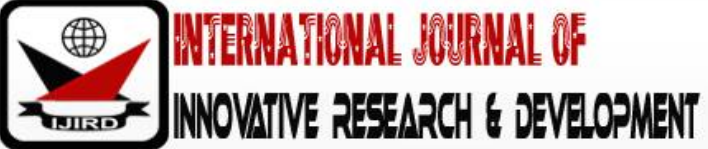

ISSN 2278-0211 (Online)

\section{Determinants of Financial Stability of Deposit Money \\ Banks in Nigeria}

\author{
Adaramola Anthony Olugbenga \\ Associate Professor, Department of Finance, Ekiti State University, Nigeria \\ Adejayan Adeola Oluwakemi \\ Lecturer, Department of Finance, Ekiti State University, Nigeria
}

\begin{abstract}
:
The study empirically investigated the determinants of financial stability of Deposit money banks (DMBs) in Nigeria. Specifically, the study examined the effect of loan ratio and capital ratio on financial stability of banks in Nigeria. The study employed research ex-post facto research design and selected eight (8) deposit money banks over a panel of five years ranging from 2013 to 2017. The study proxied return on asset as a measurement of financial stability while the loan ratio and capital ratio were proxy for lending activities and capital base of banks in Nigeria. The study applied panel regression estimates and discovered that both loan ratio and capital ratio have significant implications on bank stability. Therefore, the study concluded that loan ratio and capital ratio are the main determinants of DMBs financial stability in Nigeria. The study recommended that management of banks should ensure that they are liquid at all times to enable the bank facilitate more credit advances to creditworthy customers in order to ensure soundness and stability of the bank via income through interest rate on loan.
\end{abstract}

Keywords: Financial stability, loan and capital base, deposit money bank, Nigeria

\section{Introduction}

Banking soundness and safety is crucial for the stability of any financial system in the world. Financial system regulators understand that a loss of confidence in the banking system can have devastating consequences on the entire financial system. For this reason, banking stability has always been a top regulatory and supervisory policy objective for regulators. Nigeria, whose banking sector is ranked 'third' in Africa after South Africa and Egypt has experienced many episodes of financial and economic recession which has brought the fragility of Nigerian banking and finance to the front burner of discourse by academics and policy makers (Ozili, 2019).

Stability of the financial system in an economy is an important catalyst for economic growth due to its function in facilitating exchange of value (Swamy, 2014). The financial sector, facilitate the flow of funds from surplus households to deficit households in a more efficient manner, thereby promoting economic growth and development (Ratnovski, 2013). Consequently, Deposit money banks need to proactively study the operating environment and develop relevant strategies that would reduce the severity of their exposure to situations that are likely to affect their financial stability. Huang and Ratnovski (2011) believed that an adequate regulatory mechanism beyond the traditional reserve requirements should be enforced to address and mitigate the systemic component of funding liquidity risk among commercial banks. The reserve ratios made by each bank may not be adequate for the liquidity exposure they face as they are subjectively determined. Allam (2013) contends further that some commercial banks set their liquidity levels through mimicking behavior in liquidity choices which may also arise from learning motives.

Commercial banks have to learn, adopt and re-orient themselves to the changing environment if they are to be competitive and perform their intermediation role effectively. The banking industry just like other industry is faced with turbulence arising from increased globalization, internationalization, advancements in information, communication and technology and trade liberalization. Commercial banks therefore, ought to engage themselves in strategies that will enable them to respond to the environmental challenges in order to gain competitive advantage (Saheed, 2018).

The Central Bank of Nigeria (CBN) was established in 1957 in order to guide the activities of commercial banks in the country among other functions. Regulations and supervisions have become imperative in the enforcement of rule and regulation and also in the judgment concerning the soundness of bank asset, bank management and capital adequacy (Adeyemi \& Asaolu, 2013). Prudential guidelines issued by CBN are to reduce the level of risk to which bank creditors are exposed and Bank supervision entails enforcement of rule and regulation and judgment concerning the soundness of bank asset, its capital adequacy and management (Akinkunmi, 2014). The regulations creates an air of transparency in the operations of the banking activities; interaction among banking institutions, corporations and customers. Adeyemi and Asaolu (2013) observed that the goal of regulatory guidelines is to help banks and other financial institutions become 
stronger players and in a manner that will ensure longevity and hence higher returns to the shareholders over time as well as greater impacts on the Nigerian economy.

A strong financial system plays a critical role in enabling growth and reducing vulnerability to crises among commercial banks. This mitigates the likelihood of disruptions in the financial intermediation process that are severe enough to significantly impair the allocation of savings to profitable investment opportunities (Stein, 2011). Financial stability is therefore an essential requirement not only for monetary stability, but also for healthy development of the economy. Many studies have identified some determinants of banking stability such as financial development levels, bank efficiency and systemic interconnectedness, among others. But much of these studies have focused on developed economies. One major issue that is not clearly understood in the literature is the determinants of banking stability in emerging economies, given that their financial structure is less sophisticated than that of developed economies.

So far, the literature on determinants of financial stability of banks in Africa is rather scanty, and the studies that examine the Nigerian context are quite few that can be easily numbered. In particular, Adeyemi and Asaolu (2013), Atoi (2018), Ozili (2019), have extended research to analysis of bank stability in Nigeria while other studies like Kolapo, Ayeni and Oke (2012), Olusanya, Oyebo and Ohadebere (2012), Osuka and Osadume (2013), Adeusi, Kolapo and Aluko (2014), Akani and Uzah (2018), Osadume and Ibenta (2018), Saheed (2018) to mention but few focused attention on lending activities and commercial banks profitability. The revelation from these is that issue relating to determinants of financial stability of deposit money banks in Nigeria is relatively scarce which calls for further investigation.

More importantly, Mendoza and Terrones (2012) identified loan ratio and capital ratio cut as the biggest predictors of bank failure. Empirically, not many studies have employed the two determinants or variables simultaneously leaving a research gap to be filled in literature. Focusing on bank capital, bank regulators in Nigeria want banks to keep sufficient capital for the risks they take and to mitigate unexpected losses (CBN, 2010). However, some experts believe that capital resources alone are not sufficient to achieve bank stability in emerging economies due to debates about what constitutes bank capital (Farag, Harland \& Nixon, 2013, Ozili, 2017). Considering these arguments, it is needful to identify the determinants of banking stability in Nigeria.

\section{Literature Review}

\subsection{Conceptual Clarification}

\subsubsection{Financial Stability of Deposit Money Banks}

Banking system is aggregation and combination of financial institutions responsible for safeguarding and advancing credit facility and the provision of other financial services to the populace (CBN, 2016). Technically, deposit takers whose liabilities are included in the national definition of broad money are very significant component of the banking system. In most emerging economies where the non-bank financial institutions are still nascent, the deposit takers component of the banking system is usually huge. Hence, shock on asset side of a group of banks, through rising amount of NPLs in the credit portfolio could spillover and affect the stability of the system. A good measure of banking stability is essential for addressing issues of instability in the system (Atoi, 2018).

Financial stability describes the condition where the financial intermediation process functions smoothly thereby building confidence among users (Merga, 2013). It refers to the smooth operation of the system of financial intermediation processes between households, firms and the government through a range of financial institutions supported by a myriad of financial infrastructure (Khan, 2011). Financial stability may be hampered by both internal processes and strong shocks leading to the emergence of weak spots. Such shocks may arise from the external environment, domestic macroeconomic developments, main debtors and creditors of financial institutions, economic policies or changes in the institutional environment (Azam \& Siddiqoui, 2012). Any interaction between weak spots and shocks can result in the collapse of major financial institutions and disruption of the functions of the financial system as regards financial intermediation processes. In the extreme case, it may even lead to a financial crisis with adverse implications for the economy (Ozili, 2019). The Financial stability of commercial banks can be affected by internal and external factors. These factors can be classified into bank specific (internal) and macroeconomic variables. The internal factors are individual bank characteristics which affect the bank's performance. These factors are basically influenced by the internal decisions of management and board. The external factors are sector wide or country wide factors which are beyond the control of the company and affect the profitability of banks (Olaoye, \& Olarewaju, 2015).

Financial stability of Deposit Money Banks has been viewed by Brunnermeier, Crockett, Goodhart, Persaud and Shin (2009) as the absence of banking crises when all banks are individually stable. In terms of interdependence, Segoviano and Goodhart (2009) described banking stability as the stability of banks linked to each other either directly through the interbank deposits market and participation in syndicated loans, or through lending to common sectors and proprietary trades. In the opinion of Ozii and Thankom (2018), banking stability is viewed as the absence of abnormal disruption in credit supply, payment systems and banking services.

Delis and Staikouras (2011) and Bhattacharya, Plank, Strobl and Zechner (2002) showed that strict banking supervision can limit the ability of banks to take excessive risks and possibly improve the timing of supervisory intervention during stressed times. Barth, Caprio and Levine (2013) pointed out that banking instability may be caused by incomplete regulation or ineffective supervision although both are related and cannot be examined in isolation. Although strict supervision is desirable, Barth, Caprio and Levine (2008) in their empirical study show that strict banking supervision did not lead to greater banking stability; and Čihàk and Tieman (2007) suggest that these conflicting results are due to differences in supervision quality across countries. 


\subsection{Theoretical Framework}

In the banking literature, series of theoretical debates have been ongoing in respect to determinants of bank stability. One of such arguments is the too big to fail hypothesis (TBTFH) propounded by Mishkin in 1999. The theory contends that banks that are larger in size, complex and with greater market power are always systematically important to a country's economy. Hence, such banks are always guaranteed of government support just in case they become wounded. With this in mind, the managers of these financial intermediaries usually engage them in risk taking activities therefore, making them unstable. On the other hand, the charter value hypothesis (CVH) as modelled by Marcus (1984) asserts that banks that are larger in size, complex and with greater market power tend to have higher charter values. This in turn increases their opportunity cost of becoming bankrupt hence, deterring them from taking risky activities. Thus, such deposit money banks are always profitable, sound and stable.

\subsection{Empirical Review}

Osuagwu (2016) studied the determinants of bank profitability in the light of bank specific variables, industry related factors and macroeconomic influences, using a panel of selected banks that account for over $60 \%$ of total bank assets in Nigeria. Findings showed that bank profitability is largely determined by credit risk and other factors that relate to the internal organization of banking firms. Market concentration is significant as a determinant of bank profitability. There is no evidence of structure-conduct-performance hypothesis, however empirical results show that there is no collusive behavior amongst banks. Exchange rate is significant as a determinant of bank profitability through return on equity and non-interest margin, but not significant to return on asset as a measure of profitability. Olarewaju and Akande (2016) examined the determinants of capital adequacy in Nigerian quoted deposit money banks for the years 2005-2014. The study employed both descriptive and fixed effect panel regression. The descriptive analysis showed that the mean and median values are within the minimum values and the standard deviation shows the expected growth rate deviation for each of the identified determinants of capital adequacy. From the analysis of panel data using Cross-Sectional Specific fixed effect estimations, it is discovered that a direct relationship exists among ETA, ROA and SIZ while an inverse linear relationship that exists among ROA, CR, DEP and LIQ are statistically significant in determining the level of capital adequacy among the deposit money banks in Nigeria.

Ilaboya and Iyoha (2016) investigated the determinants of profit in the Nigerian banking sector. The study employed a panel research design, with bank specific and macroeconomic data sourced from annual reports and Central Bank of Nigeria Statistical Bulletin covering the period 2006 to 2012. The panel data were analyzed using Ordinary Least Square (OLS) statistical technique. Conventional diagnostic tests of normality, multicollinearity, heteroskedasticity, autocorrelation and misspecification were conducted. In conducting the estimation of bank specific and macro-economic characteristics and bank profit, the significant variables from fixed effect estimation of preliminary baseline regressions were extracted and regressed on PCAINDEX and TOBINS' $Q$ and the findings are: capital adequacy, economic stability, money supply, inflation rate, lending interest rate and exchange rate were statistically significant at $5 \%$ level of significance on PCAINDEX and TOBIN'S Q respectively, although the strength of their impact was not the same. Total loans and advances were not statistically significant on PCAINDEX. The study showed that the differences between the forecasting measures for bank specific conditions and macroeconomic conditions are not convincing enough to conclude on which model has higher forecasting ability for banks profitability.

Chidozie and Ayadi (2017) analysed the impact of macroeconomic dynamics on banks' profitability in Nigeria. Specifically, the study examined the impact of macroeconomic variables (Gross domestic product growth, Inflation, and Crude oil price) on banks' profitability. It also seeks to examine the significance of microeconomic variables (cost to income ratio, loan to deposit ratio; loan to total assets ratio and total assets) on banks' profitability. It analysed the impact of banking industry concentration on banks' profitability. The estimation technique follows a panel regression which studied a cross section of the banking firms while observing the heterogeneity in the individual firms. The results indicated that the ratio of cost to income market concentration, and crude oil price are negatively significant in determining changes in return on average equity while total assets is positively significant in explaining return on average equity (as a measure of profitability). Islam and Rana (2017) investigated the determinants of profitability of fifteen selected private commercial banks in Bangladesh over the period 2005-2015. The study emphasized on the internal factors that affect bank profitability. This research used panel data to explore the impact of the nonperforming loan, cost to income ratio, loan to deposit ratio, commission fees, cost of fund and operating expenses on the profitability indicators of banks like return on asset and return on equity. The experimental outcomes found strong evidence that nonperforming loan (NPL) and operating expenses have a significant effect on the profitability. Moreover, the results have shown that higher NPL may lead to less profit due to the provision of classified loans. Again, higher loan to deposit (LD) ratio and cost of fund contribute towards profitability, but their impacts are not significant in the private commercial banks of Bangladesh.

Saheed (2018) examined internal factors affecting profitability of Deposit Money Banks (DMBs) in Nigeria for the period of 2008-2016 using panel data of 14 listed banks drawn from the Nigerian Stock Exchange. Secondary data obtained from the listed Deposit Money Banks' financial statements were analyzed. The independent variables were proxied by capital adequacy, credit risk, and inflation while profitability was proxied by Return on Assets (ROA). The study adopted correlational research design to investigate the determinants of profitability of the Deposit Money Banks. Panel data techniques (fixed and random effects model) were employed to examine the effect of internal factors on profitability of the sampled listed Deposit Money Banks. Although Hausman specification test suggested that fixed effect model is more appropriate, the study used Feasible Generalized Least Square (FGLS) to underpin the outcome of the Hausman specification. The study found that internal factors had significantly influenced the deposit money 
banks'profitability over the study period. The capital adequacy had a positive and significant relationship with bank profitability while credit risk had a negative and significant relationship with bank profitability during the study period.

Ngaira and Miroga (2018) adopted a descriptive survey research design to investigate determinants of financial stability of listed commercial banks in Kenya context. The study targeted 356 employees of commercial banks which included both permanent and pensionable staff and employees on contract. Data was collected through the administration of questionnaires to the target population. The returned questionnaires were analyzed using regression analysis and the study discovered that there is significant positive influence of interest rate on financial stability of listed commercial banks in Kenya. The study further established through its finding that there is significant negative influence of operational cost on financial stability; there is significant positive influence of bank size on financial stability and lastly that liquidity positive and significantly impacted financial stability of banks in Kenya. The finding from the study propelled the conclusion that there was significant positive influence of liquidity on financial stability of listed commercial banks in Kenya.

Odundo and Orwaru (2018) determined the influence of bank size on financial stability of commercial banks in Kenya. Objectively, the study controlled bank size as banks' loan portfolio, capital strength and reliance on deposits while financial stability is measured as return on assets (ROA). Correlation research design was employed in the study to target 10 commercial banks listed at the Nairobi Securities Exchange (NSE) over the period of 7 years which ranged from 2011 to 2017. By relying on regression analysis, the study explored that bank size has a significant negative effect on bank stability; banks' loan portfolio disclosed a significant positive effect while reliance on deposit established an insignificant negative effect on bank financial stability. Nonetheless, the significant of bank size supported the too big to fail hypothesis. Ozili (2019) ascertained the determinants of banking stability in Nigeria. The study employed secondary data on banking stability, gross domestic product, regulatory capital ratio, inflation, return on asset, depth of financial system, banking concentration, non-performing loan to gross loan, and bank efficiency which were sourced from the World Bank's databank. The data cover the 2003 to 2016 period. The study employed ordinary least square of multiple regression estimates and disclosed that bank efficiency, the size of nonperforming loans, regulatory capital ratios, greater financial depth and banking concentration are significant determinants of banking stability in Nigeria. A cogent and tangible implication arising from the finding of the study is that bank should intensify its effort in addressing the nonperforming loans, capital adequacy problems issues in Nigeria.

Akani and Uzah (2018) evaluated the internal and external factors that determine banks distress in Nigeria. The study applied secondary data on monetary policy rate, treasury bill rate, broad money supply, interest rate, financial sector development and capital adequacy from 1985 to 2015 which were sourced from Central bank of Nigeria Statistical Bulletin. The data were collated and analysed using regression test which involved ordinary least square method of cointegration, unit root test, Granger causality test and Vector error correction. The empirical finding discovered that monetary policy rate and treasury bill rate have negative effect on capital adequacy ratio while growth of broad money supply, real interest rate and financial sector development have positive impact on bank capital adequacy ratio. From the finding, the study concluded significant relationship between the monetary policy, macroeconomic and internal variables and deposit money banks banking distress. Al-Homaidi, Tabash, Farhan and Almaqtari (2018) studied the determinants of Indian commercial banks profitability. Profitability of Indian banks is measured by three important variables namely, Return on Assets (ROA), Return on Equity (ROE) and Net Interest Margin (NIM). The study also used a set of independent variables such as bank-specific factors which included bank size, assets quality, capital adequacy, liquidity, operating efficiency, deposits, leverage, assets management and the number of branches. Pooled, fixed and random effects models and Generalized Method of Moments (GMM) are built on panel data of 10 years for more than 60 commercial banks of India. The study also takes into account Gross Domestic Product (GDP), inflation rate, interest rate and exchange rate as macroeconomic determinants. The results of the study show that all bank-specific factors, except the number of branches, exhibited significant impacts on profitability as measured by NIM. The findings also showed that all macroeconomic determinants used in the study are found to be significant with negative impacts on Indian commercial banks profitability. Furthermore, the results showed that bank size, number of branches, assets management ratio and leverage ratio are highly significant variables of profitability in the context of Indian commercial banks as measured by ROA.

Atoi (2018) examined non-performing loan (NPL) and its effects on the stability of Nigerian banks with national and international operational licenses using quarterly time series data from 2014:Q2 to 2017:Q2. A restricted dynamic GMM is employed to estimate the macroeconomic and bank specific drivers of NPL for each licensed category. Z-Score is constructed to proxy banking stability, and its response to shocks NPLs is examined in a panel vector autoregressive framework. The results reveal that drivers of NPLs vary across the two categories of banks, but, weighted average lending rate is a vital macroeconomic driver of NPLs for both. The results also confirmed the moral hazard hypothesis and risk return tradeoff efficient market theory. Furthermore, international banks withstand NPLs shocks in the long run, despite temporary flux in the short horizon, while the stability of national banks is susceptible to NPLs shocks in the long run. Nwude, Offor and Udeh (2018) examined the determinants of broad money demand and its stability in Nigeria over the quarterly period 1991:Q1 to 2014:Q4. With ordinary least squares and other statistical methods the results indicate that a long-run relationship exists between the real broad money aggregate and real income, domestic interest rate, inflation rate, exchange rate and foreign interest rate. Real income and exchange rate are directly related to the real broad money balances while domestic interest rate, inflation rate and foreign interest rate are inversely related to the demand for broad money. Yunusa, Oyindamola and Obidu (2019) investigated the determinants of listed Deposit Money Banks' (DMBs) survival in Nigeria. The study employed fifteen banks through the application of judgmental sampling technique. The data were analysed using robust GLS regression model. Evidence from the findings indicated that there is a positive and significant influence of liquidity, leverage, profitability, solvency and asset management on DMBs' going concern (GC). 
Based on the conclusion of the study, it was concluded that liquidity, leverage, profitability, solvency and asset management were the main relevant and determinant of deposit money banks in Nigeria.

\section{Research Method}

\subsection{Research Design, Population and Sample Size}

In order to be properly and adequately guided, the study employs ex-post facto research design which accounts for the past records and happenings in relation to future occurrences in the study area. Notably, there are 23 deposit money banks registered with NSE but 8 of them namely ( First bank, United bank of Africa, Eco bank, Access bank, Union bank, Wema bank, Unity bank and Zenith bank) that have been in existence and in operation over a decade were selected for the study purpose.

\subsection{Model Specification, Measurement and Sources of Variables, and Analytical Technique}

The empirical model of this study is based on the model employed by Odundo and Orwaru (2018) where the study established a link among the determinants of bank stability in Kenya. Their model was stated as financial stability is a function of bank size, loan ratio, capital ratio, deposit ratio. However, the present study only picked loan ratio and capital ratio as main determinants of bank stability. The justification of this is because bank capital and abnormal credit are the two biggest predictors of bank failure (Mendoza \& Terrones, 2012).

Mathematically, the model applicable in this study is stated as:

$F S=f(L R, C R)-----------------------3.1$

Where; FS = Financial stability; $\mathrm{LR}=$ Loan ratio; $\mathrm{CR}=$ Capital ratio

In econometric terms, the model is restated as:

$F S=\alpha_{0}+\alpha_{1} L R_{t}+\alpha_{2} C R_{t}+U_{t}----------------3.2$

Financial stability is measured using the banks' return on assets (ROA) in line with the works of Onuonga (2014), Obamuyi (2013). It was sourced from Annual statement of banks account.

Loan Ratio- this is operationalized using the ratio of loans to total assets, similar to Onuonga (2014). It is included as an independent variable to account for the effect of the banks' lending activities. It was sourced from Annual statement of banks account.

Capital ratio- this is proxied by the ratio of equity/total assets as used in Onuonga (2014). It is included as an independent variable in order to account for the effects of larger capital bases in the banks. It was sourced from Annual statement of banks account.

Therefore, data on financial stability, loan ratio and capital ratio from 2013 to 2017 were sourced from Annual statement of respective banks. For easy analysis, this study adopts the panel regression estimates. This analysis is based on fixed regression and random regression analysis, however, the Hausman test was employed to ascertain the best model applicable in the study for suitability. Having established the exact model between fixed regression and random regression, other estimation tests that are considered are t-test, f-test, $\mathrm{R}^{2}$ test, Adj $\mathrm{R}^{2}$ test and Durbin Watson test.

\subsection{Apriori Expectation}

$\frac{\partial L R}{B S}>0 ; \frac{\partial C R}{B S}>0$.

It is expected that at the end of the study, both loan ratio and capital ratio would positively affect financial stability of Deposit money banks in Nigeria.

\section{Result and Discussion}

\subsection{Result of the Model Estimation Test}

The Hausman test was used to select the best model, that is, either the fixed effect (F.E) model or the random effect (R.E) model to analyse the panel data under the null hypothesis.

Hausman Test Hypothesis:

- $\mathrm{H}_{0}$ : Random effect model is appropriate

- $\mathrm{H}_{1}$ : Fixed effect model is appropriate

NB: If the probability value is statistically significant, the study will use fixed effect mode, otherwise, random effect model.

\begin{tabular}{|c|c|c|c|}
\hline Test Summary & Chi-Sq. Statistic & Chi-Sq. d.f. & Prob. \\
\hline Cross-section random & 3.217478 & 1 & 0.6665 \\
\hline
\end{tabular}

Table 1: Extract from the Hasuman Test Results

Source: Author's Computation (2020), E-view 9.0 version

Looking at the Chi-square values of the cross-section random in Table 4.1, the probability values of the chi-square statistics is 66.65 percent which is greater than $5 \%$, this implies that the study cannot reject the null hypotheses; rather accept the null hypotheses, hence, the random effect model is the appropriate model to accept for analytical reasons. 


\subsection{Presentation of Random Regression Results}

The Table 2 showed the regression of the ordinary least square results conducted on the specified model with Eview 9.0. The OLS results revealed the relationship that exists between the dependent variable and each of the independent variable.

\begin{tabular}{|c|c|c|c|c|}
\hline \multicolumn{5}{|c|}{$\begin{array}{c}\text { Date: } 02 / 12 / 20 \text { Time: } 06: 02 \\
\text { Sample: } 20132017 \\
\text { Periods included: } 8 \\
\text { Cross-sections included: } 3 \\
\text { otal panel (balanced) observations: } 24\end{array}$} \\
\hline Variable & Coefficient & Std. Error & t-Statistic & Prob. \\
\hline C (FS) & 2.968025 & 0.389754 & 7.615119 & 0.0000 \\
\hline LR & 1.187348 & 0.119723 & 9.917437 & 0.0000 \\
\hline CR & 0.115741 & 0.037856 & 3.057434 & 0.0060 \\
\hline & \multicolumn{2}{|c|}{ Effects Specification } & & \\
\hline & & & S.D. & Rho \\
\hline \multicolumn{3}{|c|}{ Cross-section random } & 2.235544 & 0.9930 \\
\hline \multicolumn{3}{|c|}{ Idiosyncratic random } & 0.188275 & 0.0070 \\
\hline & Weightec & tatistics & & \\
\hline R-squared & 0.954847 & \multicolumn{2}{|c|}{ Mean dependent var } & 3.487864 \\
\hline Adjusted R-squared & 0.948396 & \multicolumn{2}{|c|}{ S.D. dependent var } & 0.522001 \\
\hline S.E. of regression & 0.118580 & \multicolumn{2}{|c|}{ Sum squared resid } & 0.295285 \\
\hline F-statistic & 148.0280 & \multicolumn{2}{|c|}{ Durbin-Watson stat } & 1.660668 \\
\hline \multirow[t]{2}{*}{ Prob(F-statistic) } & 0.000000 & & & \\
\hline & \multicolumn{2}{|c|}{ Unweighted Statistics } & & \\
\hline R-squared & 0.914020 & \multicolumn{2}{|c|}{ Mean dependent var } & 2.760908 \\
\hline Sum squared resid & 0.057269 & \multicolumn{2}{|c|}{ Durbin-Watson stat } & 1.622510 \\
\hline
\end{tabular}

The relationship between the dependent variable (financial stability) and the explanatory variables of loan ratio and capital ratio in the Table 2 can be expressed mathematically as:

$\mathrm{FS}=2.968025+1.187348_{\mathrm{LR}}+0.115741_{\mathrm{CR}}+\mu$

\subsection{Interpretation and Discussion of Findings}

An examination of the results of the data in Table 4.1 showed that if all the explanatory variables were held constant, bank financial stability will positively increase by 2.968025 units and statistically significant. The coefficient of loan ratio and capital ratio which were estimated to be 1.187348 and 0.115741 were positive and significantly related to banks' financial stability in Nigeria under the study period. This implies that an increase in credit facility and capital base of the DMBs will lead to an increase in financial stability of Nigerian banks. The coefficient of multiple determinations ( $\mathrm{R}^{2}$ ) and Adj R ${ }^{2}$ were denoted as 0.954847 and 0.948396 which justified the influencer power of loan and credit ratio on financial stability of banks. This implied that the explanatory variables have potency of about $95 \%$ on bank stability in Nigeria leaving the remaining 5\% to stochastic error term. More importantly, the probability of the F-test signified that the whole model is significant. Analysis of the DWT indicated that 1.66 is much closer to 2, hence serial autocorrelation is not a problem to the study but rather makes the model suitable, reliable, dependable and unbiased for policy formulation.

Empirically, it has been established that loan and capital ratio are determinants of bank stability in Nigeria. The implication of this is that the more credit a bank is able to advance to its credit worthy customers, the more the profit available to the bank. It further implies that banks with larger capital bases are more stable as they are able to diversify their business operations, thus strengthening their ability to assume risk (Odundo \& Orwaru, 2018).

\section{Conclusion and Recommendations}

Evidence from the research findings indicated that both loan ratio and capital ratio are good determinants of banks stability in Nigeria. These results are in consistence with the existing empirical studies of Hoffmann (2011), Obamuyi (2013), Onuonga (2014) as well as Odundo and Orwaru (2018) that loan ratio and capital ratio significantly affect bank stability. The finding is in alignment with the too big to fail hypothesis on the note that larger banks do receive guarantee from government as support in case they wound up. To this end, the study concluded that bank lending and capital base are the main determinants of financial stability of deposit money banks in Nigeria. The study suggested that the management of banks should ensure that they are liquid at all times to enable the bank facilitate more credit advances to creditworthy customers in order to ensure soundness and stability of the bank via income through interest rate on loan. The study further suggested that proactive and effective policies that are capable of maintaining higher capital bases are enforced in order to enhance the soundness and stability of the banks. 


\section{References}

i. Adeusi, S. O., Kolapo, F. T., \& Aluko, A. O. (2014). Determinants of commercial banks' profitability panel evidence from Nigeria. International Journal of Economics, Commerce and Management, 2(12), 1-18.

ii. Adeyemi, A. A., \& Asaolu, T. (2013). An empirical investigation of the financial reporting practices and banks' stability in Nigeria. Kuwait Chapter of Arabian Journal of Business and Management Review, 2(5), 157-180.

iii. Akani, H. W., \& Uzah, C. K. (2018). Determinants of bank distress in Nigeria commercial banks: A multidimensional study. International Journal of Innovative Finance and Economics Research 6(4), 67-87.

iv. Akinkunmi, M. A. (2014). Determinants of banks' profitability in Nigeria: Does relative market power matter? Journal of Finance and Bank Management, 5(1), 42-53.

v. Al-Homaidi, E. A., Tabash, M. I., Farhan, N. H. S., \& Almaqtari, F. A. (2018). Bank-specific and macro-economic determinants of profitability of Indian commercial banks: A panel data approach. Cogent Economics \& Finance, 6, 1-26.

vi. Allam, A. M. (2013). Financial risk management: models, history, and institutions (Vol. 538). John Wiley \& Sons.

vii. Atoi, N. V. (2018). Non-performing loan and its effects on banking stability: Evidence from national and international licensed banks in Nigeria. CBN Journal of Applied Statistics, 9(2), 43-74.

viii. Azam, M., \& Siddiqui, S. (2012). Domestic and foreign banks' profitability: Differences and their determinants. International Journal of Economics and Financial Issues, 2(1), 33-42.

ix. Barth, J. R., Caprio, G., \& Levine, R. (2006). Rethinking bank regulation, Cambridge books, Cambridge University Press, Cambridge. Barth, J. R., Caprio, R. and Levine, R. (2008), Bank regulations are changing: for better or worse? Comparative Economic Studies, 50(4), 537-563.

x. Barth, J. R., Caprio, G., \& Levine, R. (2013). Bank regulation and supervision in 180 countries from 1999 to 2011. Journal of Financial Economic Policy, 5(2), 111-219.

xi. Bhattacharya, S., Plank, M., Strobl, G., \& Zechner, J. (2002). Bank capital regulation with random audits. Journal of Economic Dynamics and Control, 26(7), 1301-1321.

xii. Brunnermeier, M. K., Crockett, A., Goodhart, C. A., Persaud, A., \& Shin, H. S. (2009). The fundamental principles of financial regulation, 11. International Center for Monetary and Banking Studies (ICMB), Geneva.

xiii. CBN (2010). Prudential guidelines for deposit money banks in Nigeria. Available at: https://www.cbn.gov.ng/out/2010/publications/bsd/prudential\%20guidelines\%2030\%20june\%202010\%20fin al\%20\%20_3_pdf.

xiv. Central Bank of Nigeria (2016). Understanding monetary policy and financial concepts.

xv. Chidozie, U. E., \& Ayadi, F. S. (2017). Macro-economy and Banks' Profitability in Nigeria. African Research Review, An International Multi-Disciplinary Journal, Ethiopia, 11(46), 121-137.

xvi. Delis, M. D., \& Staikouras, P. K. (2011). Supervisory effectiveness and bank risk. Review of Finance, 15(3), $511-543$.

xvii. Farag, M., Harland, D., \& Nixon, D. (2013). Bank capital and liquidity. Bank of England Quarterly Bulletin, Q3.

xviii. Huang, R., \& Ratnovski, L. (2011). The dark side of bank wholesale funding. Journal of Financial Intermediation, 20(2), 248-263.

xix. Ilaboya, O. J., \& Iyoha, A. I. (2016). Determinants of profit in the Nigerian banking sector. Research Journal of Finance and Accounting, 7(19), 65-77.

xx. Islam, A., \& Rana, R. H. (2017). Determinants of bank profitability for the selected private commercial banks in Bangladesh: a panel data analysis. Banks and Bank Systems, 12(3), 179-192.

xxi. Kolapo, T. F., Ayeni, R. K., \& Oke, M. O. (2012). Credit risk and commercial banks' performance in Nigeria: A panel model approach. Australian Journal of Business and Management Research, 2(02), 31-38.

xxii. Marcus, A. J. (1984). Deregulation and bank financial policy. Journal of Banking and Finance, 8, 557-565.

xxiii. Mendoza, E. G., \& Terrones, M. E. (2012). An anatomy of credit booms and their demise. No. W18379. National Bureau of Economic Research.

xxiv. Mishkin, F. S. (1999). Financial consolidation: Dangers and opportunities. Journal of Banking and Finance 23: 675691.

xxv. Ngaira, A. P., \& Miroga, J. (2018). Determinants of financial stability of listed commercial banks in Kenya. The Strategic Journal of Business and Change Management, 5(4), 1074-1097.

xxvi. Nwude, E. C., Offor, K. O., \& Udeh, S. N. (2018). Determinants and stability of money demand in Nigeria. International Journal of Economics and Financial Issues, 8(3), 340-353.

xxvii. Obamuyi, T. M. (2013). 'Determinants of banks' profitability in a developing economy: Evidence from Nigeria. Organizations and markets in emerging economies (2), 97-111.

xxviii. Odundo, O. G., \& Orwaru, M. J. (2018). Bank size and financial stability of commercial banks in Kenya: Empirical evidence. Journal of Emerging Issues in Economics, Finance and Banking (JEIEFB), 7(1), 2667-2680.

xxix. Olaoye, F. O., \& Olarewaju, O. M. (2015). Determinants of deposit money banks' profitability in Nigeria. Kuwait Chapter of Arabian Journal of Business and Management Review, 4(9).

xxx. Olarewaju, O. M., \& Akande, J. O. (2016). An empirical analysis of capital adequacy determinants in Nigerian banking sector. International Journal of Economics and Finance, 8(12), 132-142.

xxxi. Olusanya, S. O., Oyebo, A. O., \& Ohadebere, E. C. (2012). Determinants of lending behaviour of commercial banks: Evidence from Nigeria, A co-integration analysis (1975-2010). Journal of Humanities and Social Science (JHSS), 5(5), 71-80.

xxxii. Onuonga, S. M. (2014). The analysis of profitability of Kenyas top six commercial banks: Internal Factor Analysis. American International Journal of Social Sciences 3(5), 94-103. 
xxxiii. Osadume, R., \& Ibenta, S. (2018). Evaluation of the financial performance of deposit money banks in Nigeria (2001 - 2014). International Institute of Academic Research and Development, 4(2), 23-50.

xxxiv. Osuagwu, E. S. (2016). Determinants of bank profitability in Nigeria. International Journal of Economics and Finance, 6 (12), 46-63.

xxxv. Osuka, B. O., \& Osadume, C. R. (2013). The determinants of financial performance of quoted banks in Nigeria: A study of selected deposit money banks (DMBs) (2001 - 2010). International Journal of Education and Research, 1(10), 1-18.

xxxvi. Ozili, P. K. (2019). Determinants of banking stability in Nigeria. Electronic copy available at: https://ssrn.com/abstract=3392963.

xxxvii. Ozili, P. K., \& Thankom, A. G. (2018). Income smoothing among European systemic and non-systemic banks. The British Accounting Review, 50(5), 539-558.

xxxviii. Ratnovski, L. (2013). Liquidity and transparency in bank risk management. Journal of Financial Intermediation, 22(3), 422-439.

xxxix. Saheed, A. M. (2018). Determinants of listed deposit money banks' profitability in Nigeria. International Journal of Science, International Journal of Finance and Banking Research, 4(3), 40-56.

xl. Segoviano, M. A., \& Goodhart, C. A. E. (2009). Banking stability measures No. 627, International Monetary Fund Working Paper No. 04. International Monetary Fund, Washington, DC.

xli. Swamy, V. (2014). Testing the interrelatedness of banking stability measures. Journal of Financial Economic Policy, 6(1), 25-45.

xlii. Yunusa, A., Oyindamola, E., \& Obidu, Q. M. (2019). Determinants of survival of listed deposit money banks in Nigeria. European Journal of Accounting, Auditing and Finance Research, 7(3), 20-40. 